\title{
SUMMARY OF MECHANICAL PROPERTIES FOR JBK-75 FORGINGS
}

Robert L. Page

Robert W. Krenzer

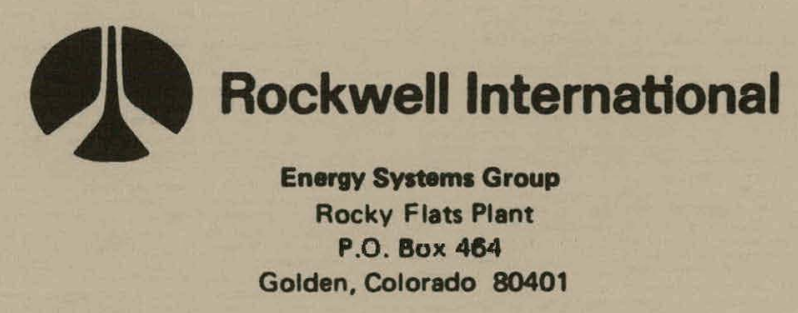

U. S. DEPARTMENT OT ENERGY CONTRACT DE-AC04-76DPO3533 


\section{DISCLAIMER}

This report was prepared as an account of work sponsored by an agency of the United States Government. Neither the United States Government nor any agency Thereof, nor any of their employees, makes any warranty, express or implied, or assumes any legal liability or responsibility for the accuracy, completeness, or usefulness of any information, apparatus, product, or process disclosed, or represents that its use would not infringe privately owned rights. Reference herein to any specific commercial product, process, or service by trade name, trademark, manufacturer, or otherwise does not necessarily constitute or imply its endorsement, recommendation, or favoring by the United States Government or any agency thereof. The views and opinions of authors expressed herein do not necessarily state or reflect those of the United States Government or any agency thereof. 


\section{DISCLAIMER}

Portions of this document may be illegible in electronic image products. Images are produced from the best available original document. 
This report was prepared as an account of work sponsored by the United States Government. Neither the United States nor the Department of Energy, nor any of their employees, nor any of their contractors, subcontractors, or their employees, makes any warranty, expressed or implied, or assumes any legal liability or responsibility for the accuracy, completenesss or usefulness of any information, apparatus, product or process disclosed, or represents that its use would not infringe privately owned rights.

Printed in the United States of America

Available from the

National Technical Information Service

U. S. Department of Commerce

Springfield, Virginia 22161

Price: Printed Copy $\$ 4.50$ Microfiche $\$ 3.00$

Price Is Subject to Change Without Notice 


\title{
SUMMARY OF MECHANICAL PROPERTIES FOR JBK-75 FORGINGS
}

\author{
Robert L. Pagé
}

Robert W. Krenzer

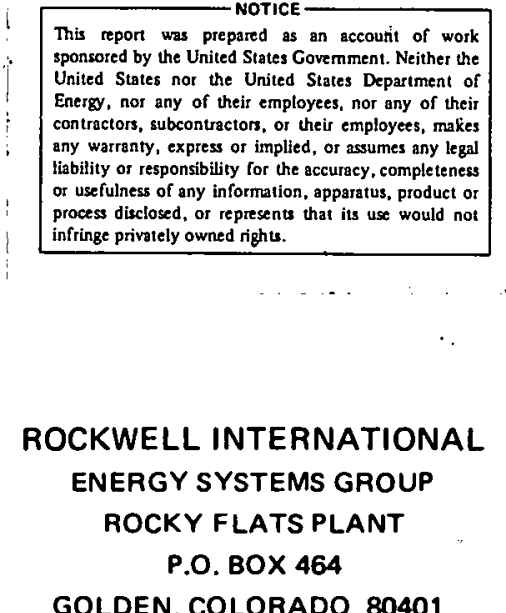

GOLDEN, COLORADO 80401

Prepared under Contract DE-AC04-76DPO3533 for the Albuquerque Operations Office U.S. Department of Energy 


\section{CONTENTS}

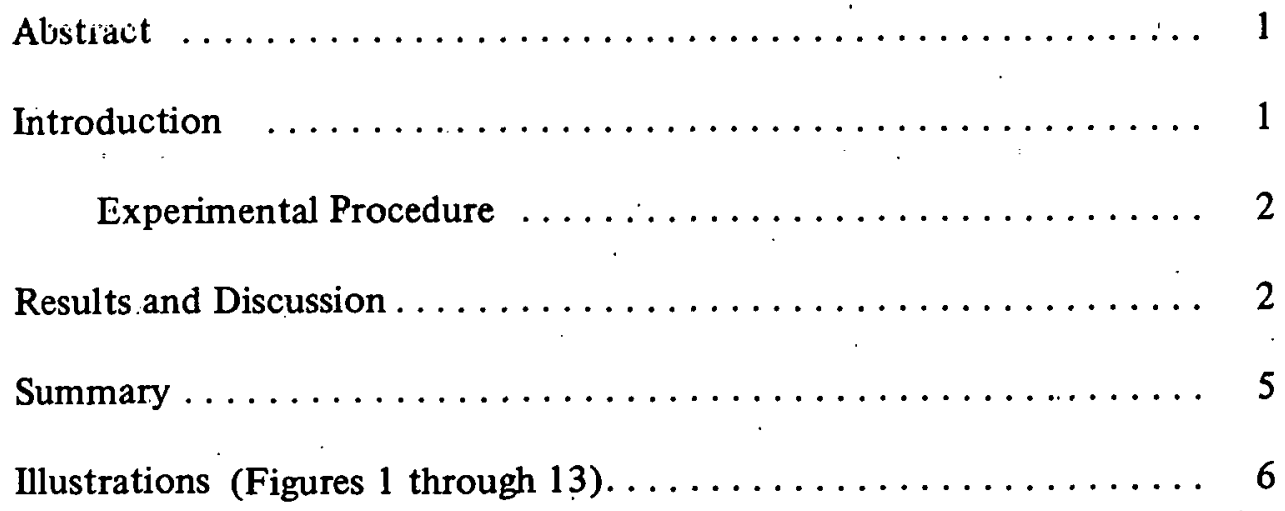




\title{
SUMMARY OF MECHANICAL PROPERTIES FOR
}

\author{
JBK-75 FORGINGS
}

\author{
Robert L. Page and Robert W. Krenzer
}

\begin{abstract}
Increased strengths can be achieved in precipitation-hardened stainless steels by deforming the steel and retaining a worked structure prior to aging. JBK-75 is one example of a superalloy which will respond to this type of thermomechanical processing. The present study was undertaken to determine the tensile properties of different forged shapes resulting from the combined effects of strain hardening and precipitation hardening. Various size bar stock was deformed by High Energy Rate Forging (HERF) and subsequently aged. Resultant tensile properties were quite variable, showing a wide range of strengths and ductilities, well below expected values. The tensile properties were strongly dependent upon forging geometry.
\end{abstract}

\section{INTRODUCTION}

Rocky Flats is currently involved in an extensive experimental program to establish a production process for fabricating component parts from JBK-75. In order to meet design requirements, it is necessary to retain a worked structure in the material to achieve increased strengths. However, unlike 304 or 21-6-9 stainless steels, JBK-75 is a more complex alloy involving numerous metallurgical reactions which influence the microstructure and/or mechanical properties at any stage of the process. Thermomechanical processing of a superalloy to achieve uniform mechanical properties in complex shapes is a subject which is not fully understood.

Major factors influencing microstructural control in JBK-75 include homogenization temperature, solution treatment temperature, deformation temperature, degree of deformation and aging time and temperature. Two phases that play a major role in the mechanical properties of JBK-75 include spherical $\gamma^{\prime}, \mathrm{Ni}_{3}(\mathrm{Al}, \mathrm{Ti})$, the coherent precipitate responsible for strengthening; and $\eta, \mathrm{Ni}_{3} \mathrm{Ti}$, the equilibrium incoherent phase associated with overaging and loss of strength and ductility.
Optimum size for the spherical $\gamma^{\prime}$ phase is 100 $200 \AA$ and, consequently, this phase cannot be seen with conventional optical microscopes. The lamillar $\eta$ phase, however, is very similar in morphology to the pearlitic phase in carbon steels, and typical examples are shown in Figure 1 from an early forging and in Figure 2 decorating titanium rich regions of a chemically segregated (banded) structure. The specific temperature range where these two phases are stable in JBK-75 is unknown. However, in a similar alloy, A-286, the approximate temperature range for aging or formation of $\gamma^{\prime}$ is $500-800^{\circ} \mathrm{C}$ and the approximate range of $\eta$ formation is $500-910^{\circ} \mathrm{C}$. Between $860-910^{\circ} \mathrm{C}, \eta$ forms directly from the $\gamma$ matrix. The recrystallization temperature should be somewhere slightly above the $\eta$-solvus temperature, $910^{\circ} \mathrm{C}$. For JBK-75 witl its higher nickel content, these temperatures may shift on the order of $25^{\circ} \mathrm{C}$ higher.

Superalloys like JBK-75 are process history sensitive, which means that changes in melting practice, forging or heat treatment schedules can have a significant effect on resulting propterties. This report deals with one aspect of this process; that is, the aging response and the resultant tensile properties obtained in the six different forged shapes shown in Figure 3.

It was of particular interest to determine if required strengths could be achieved without severe losses in ductility, and to determine uniformity of aging response as a function of forging geometry. The minimum mechanical properties specified by Sandia Livermore Labs at the time of this study were:

$\begin{array}{ll}\text { Ultimate Tensile Strength } & =165 \mathrm{ksi} \\ 0.2 \% \text { Tensile Yield Strength } & =130 \mathrm{ksi} \\ \text { Uniform Elongation } & =8 \% \\ \text { Reduction in Area } & =40 \%\end{array}$


Experimental Procedure

Six different forging geometries were investigated. Each type was sectioned to adequately represent the complexities of geometry. A typically sectioned forging is shown in Figure 4 along with orientation terms used in this report. Two or more radial sections were normally machined from each forging to add statistical validity to the values obtained for each specimen location.

Tensile bars were machined from selected regions representative of the part location. Initially, specimens were machined after aging of the section but currently all specimens are aged after machining. There was no detectable difference attributable to the aging sequence. The dimensions of the tensile bars used are shown in Figure 5. Microtensile bars must be used to obtain mechanical properties of very small sections or of very specific locations. However, it has been shown in other studies, that ductility values from microtensile specimens exhibit less precision than R-4 and R-5 specimens; consequently, larger tensile specimens were used to obtain more reliable elongations and reductions in area. A crosshead speed of $0.2 \mathrm{in} . / \mathrm{min}$. was used and elongation was determined utilizing a 0.5 in. extensometer, a 0.5 in. extensometer modified to 0.25 in., a constant chart speed, and reconstruction of the fractured tensile specimen. Currently, constant chart speed is used with microtensile specimens and a $0.5 \mathrm{in}$. extensometer with the two larger ternsile specimens.

A definition of the values obtained from the loadextension chart of a tensile test is shown in Figure 6. It was discovered only recently that Sandia Livermore Labs had been reporting uniform elongation values which included elastic strain. Elastic strain contribution, however, can be calculated from the nominal elastic modulus (Y) and the reported ultimate tensile strength (UTS) as follows:

$$
\text { Percent Elastic Strain }=\frac{\text { UTS }}{\mathrm{Y}} \times 100
$$

Where: $Y=26.3 \times 10^{6}$ psi as calculated from recent tests of R-5 specimens from actual forgings.
This value could also be used as an approximation for the contribution of percent elastic strain to total elongation, although the value will be somewhat high as specimen failure normally occurs nearer the tensile yield load. All elongations reported here are plastic plus elastic using the above formula when required.

\section{RESULTS AND DISCUSSION}

For traceability, the melting practice and chemistry of the heats of bar stock used for the forgings in this study are included in Table 1. Rocky Flats is currently developing a forgeability test that will permit evaluation of bar stock with respect to properties obtainable with specified forging parameters. In addition, a thermomechanical test procedure is being developed to determine the relative severity of chemical segregation (banding) in as-received bar stock.

In general, the first forgings evaluated all utilized similar forging parameters. The early stages of forging were done at $\sim 1850^{\circ} \mathrm{F}$ with air cooling between stages. This results in $\eta$ phase precipitation which often is not resolutionized in the final forging stage at $1650^{\circ} \mathrm{F}$. It has since been learned that the work retained at the $1650^{\circ} \mathrm{F}$ forging temperature greatly accelerates $\eta$ phase precipitation. The result was that all early forgings exhibited nonuniform strengths, low ductility, and some degree of $\eta$ phase precipitation. In addition, the strain rate sensitivity of superalloys such as JBK-75 at these low-forging temperatures may lead to "adiabatic shear planes" or the less severe "feathering" depicted in Figure 7. One or both of these defects was observed in at least one of each type of toroid forging.

Forging temperatures were then raised to $\geqslant 1725^{\circ} \mathrm{F}$ (above the $\eta$ solvus) for all forging stages, with water quench after each stage. Using these latest forging parameters the $\eta$ phase is rarely observed in sectioned forgings and ductilities are improved, but nonuniform properties and microstructure continue to be of concern.

General forging development and current properties for each of the six forging types are discussed in the 
TABLE 1. Forging Bar Stock Chemistries

\begin{tabular}{|c|c|c|c|c|c|c|}
\hline \multicolumn{2}{|c|}{$\begin{array}{l}\text { Vendor } \\
\text { Heat No. } \\
\text { Melting* } \\
\text { Practice }\end{array}$} & $\begin{array}{c}\text { Simonds } \\
\text { T-6787 } \\
\text { VIM } \\
\text { VAR }\end{array}$ & $\begin{array}{c}\text { Teledyne } \\
\text { H-926 } \\
\text { VIM } \\
\text { ESR }\end{array}$ & $\begin{array}{c}\text { Teledyne } \\
\text { H-927 } \\
\text { VIM } \\
\text { ESR } \\
\end{array}$ & $\begin{array}{c}\text { Allvac } \\
2448 \\
\text { VIM } \\
\text { VAR } \\
\end{array}$ & $\begin{array}{l}\text { Cartech } \\
93491 \\
\text { VIM } \\
\text { VAR } \\
\end{array}$ \\
\hline \multirow{13}{*}{ 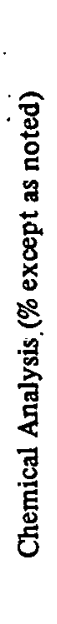 } & $\mathrm{C}$ & 0.013 & 0.024 & 0.024 & 0.019 & 0.015 \\
\hline & $\mathbf{S}$ & 0.012 & 0.002 & 0.002 & 0.003 & 0.002 \\
\hline & $\mathrm{Ni}$ & 30.74 & 30.45 & 30.09 & 30.00 & 29.20 \\
\hline & $\mathbf{M n}$ & 0.16 & $<0.01$ & 0.005 & 0.02 & 0.003 \\
\hline & $\mathbf{P}$ & 0.011 & 0.004 & 0.004 & 0.005 & 0.002 \\
\hline & $\mathrm{Si}$ & 0.09 & 0.04 & 0.03 & $<0.01$ & 0.01 \\
\hline & Mo & 1.23 & 1.30 & 1.32 & 1.36 & 1.20 \\
\hline & $\mathrm{Cr}$ & 14.33 & 14.42 & 14.28 & 14.35 & 14.10 \\
\hline & o & 25 ppm & $22 \mathrm{ppm}$ & 22 ppm & - & $30 \mathrm{ppm}$ \\
\hline & $\mathrm{Ti}$ & 1.89 & 2.21 & 2.12 & 2.18 & 2.18 \\
\hline & $\mathbf{v}$ & 0.20 & 0.30 & 0.31 . & 0.33 & 0.41 \\
\hline & $\mathbf{A l}$ & 0.12 & 0.28 & 0.26 & 0.31 & .0 .30 \\
\hline & B & $<5$ ppm & $<10$ ppm & $<10$ ppm & $<10$ ppm & $<5$ ppm \\
\hline
\end{tabular}

*VIM = Vacuum Induction Melt, VAR = Vacuum Arc Remelt ESR $=$ Electro-Slag Remelt

following paragraphs. All forgings are currently being evaluated for mechanical properties according to a standardized test procedure supplied by SLL. Specimen type and location are specified using templates as shown (in reduced scale) in Figures 8 through.13. In all cases the larger specimen is the non-standard SLL special 1/8 in. diameter gage tensile specimen, and the smaller specimen (used on Die 807 and 865 forgings only) is the micro-tensile specimen which was used exclusively on earlier forgings. Specimen identification has also been standardized using the three digit number for forging type, a sequencial number related to the relative significance of mechanical properties, and a letter designating the orientation (e.g. $\mathrm{A}=$ Axial, $\mathrm{H}=$.Hoop, $\mathrm{C}=$ Circumferential).

Figure 8 shows the mechanical properties and grain flow of the stem forging, Die 807. This forging is unique in that dual properties are deliberately achieved. The body needs the same mechanical properties as the other five forgings, but in order to pinch weld the stem in the area of specimen $5 \mathrm{~A}$, a stem hardness of $\angle R_{c} 30$, which requires virtually annealed-aged properties, has been specified. This is nominally $<100 \mathrm{ksi}$ yield strength and is achieved by upsetting just the heat in the last forging operation. The $1725^{\circ} \mathrm{F}$ forging temperature should fully anneal the stem. As shown in the grain flow macrograph, die erosion has led to some upsetting rather than the sharp shoulder indicated by the forging dimension outline. The small, sharp upper shoulder was machined in the forging to facilitate sectioning. The die erosion has let to some upsetting in the region of $5 \mathrm{~A}$ on the last forging operation and has resulted in properties somewhat higher than anticipated. The remainder of the forging meets mechanical property specifications. With new die materials this forging should achieve both the grain flow and the duplex properties desired. 
The mating part to the Die 807 forging is obtained from the Cap forging, Die 865 . This forging was redesigned from the older Die 808 forging shown in Figure 3 because of the shear planes consistently found in this forging. As the mechanical properties indicate, this forging easily exceeds the current specification. The grain size of this forging is so uniformly fine and grains so free of texturing that a grain flow macrograph could not be obtained from any of the current forgings.

The large outer toroid forging, Die 809, shown in Figure 10 exhibits both mechanical property and grain flow problems. Considering that the orientation shown is upside down with respect to the actual forging orientation, it is apparent that only the upper portion of this rather full forging is receiving adequate work in the last forging stage. The properties of specimen $2 \mathrm{H}$ from the most recent forgings are well within specification, but strengths decrease towards the other end of the forging in the hoop direction. Possibly of more concern is that the prior forgings of the same bar stock and forging parameters (only specimens $2 \mathrm{H}$ and $3 \mathrm{H}$ obtained) exhibit strengths much higher with elongations $\left(\mathrm{E}_{\mathrm{u}}\right)$ below specifications. If, indeed, all forging conditions were the same, this kind of variation would be unacceptable for production. Grain flow in the area of specimens $3 \mathrm{H}$ and $3 \mathrm{C}$ has no clear texture.

The large inner toroid forging Die 810 , shown in Figure 11 , has consistently exhibited problems with low strengths. The early forgings were final-forged at $1650^{\circ} \mathrm{F}$ to maximize retained work. However, these forgings resulted in $\eta$ phase and shear planes shown in Figure 7. Even with the low forging temperatures, a relatively "dead" area exists in the region of specimens $3 \mathrm{H}$ and $3 \mathrm{C}$ which yields properties only slightly higher than annealed-aged JBK-75. Shear planes and $\eta$ phase precipitation were effectively eliminated by increasing the final forging temperature to $1725^{\circ} \mathrm{F}$; but, as might be expected, properties were lower (data not shown). In an attempt to increase properties without re-incurring $\eta$ phase precipitation and shear planes, the parts were removed from the furnace at the specified final forging temperature and air-cooled a specified time prior to forging. Apparently the kinetics of $\eta$ phase precipitation is slow enough to permit the resultant lower forging temperatures without precipitation. This technique has not yet resulted in shear planes either. However, as indicated by the last two forging lots, the relatively "dead" area persists. In comparing data from the two ends of different forging lots for this part, one must realize that the symmetry of this forging does not permit defining a top and bottom as has been done arbitrarily in the sketches.

The small outer toroid forging Die 811 , shown in Figure 12, also has both a strength and grain flow problem. Although not apparent in the sketches, the part contour curvature is virtually the opposite of the flow line curvature shown. This is probably caused by buckling of the back extrusion as suggested by Precision Forge (Vern Marlow). Since the mechanical properties of this forging are somewhat low, future forgings will incorporate a 30,60, and 90 second air cool prior to forging. Earlier forgings of this configuration were not sampled in the location or orientations currently specified, therefore they have not been included in this report.

Recent development of the small inner toroid forging Die 81.2 shown in Figure 13 closely paralleled that of the Die 810 forging. Currently this forging utilizes the same bar stock and early stages of tooling as the Die 810 forging. The 812 forging also exhibits a similar (although less severe) relatively "dead" area in the region of specimens $3 \mathrm{H}$ and $3 \mathrm{C}$. The two most recent lots of these forgings illustrates the direction of forging development for this part. Using forging parameters that eliminate $\eta$ phase precipitation and shear planes, the yield strength of the relatively "dead" area $3 \mathrm{H}$ has been increased from $117.5 \mathrm{ksi}$ to $125 \mathrm{ksi}$ with a 30 second air cool just prior to forging. Future forgings will utilize a 30,60, and 90 second hold in an attempt to meet specified properties in this area. The only problem with this HERF forging technique is that the air cool prior to forging tends to enhance the amount of retained work without $\eta$ phase precipitation, but does nothing to make the properties more uniform. Consequently, high strength areas such as area $1 \mathrm{H}$ 
may fall below the minimum uniform elongation specification (8\%) as its yield strength is increased concurrently with area $3 \mathrm{H}$. This forging also exhibited $\eta$ phase and shear planes when final forged at $1650^{\circ} \mathrm{F}$.

\section{SUMMARY}

Since the beginning of actual hardware forging development nearly two years ago, much has been learned about JBK-75 and the effect of HERF on the alloy. Eta phase precipitation and shear planes which plagued early forgings have virtually been eliminated. However, nonuniform mechanical properties within a given forging have not diminished and is probably an inherent characteristic of the HERF process and a need to retain work in the forging. Despite this, the HERF techniques developed by Precision Forge and SLL have come very close to bridging the gap between minimum strength in low strength regions at a given forging, and minimum ductility $\left(E_{u}\right)$ in high strength regions of the same forging. Considerable work is still required to demonstrate that a given forging process can produce mechanical properties that are repeatable within the specified limits from lot to lot with various heats of bar stock. Because die design has been held constant during development of mechanical properties, the remaining grain flow problems have not been addressed. Grain flow problems, however, are more readily solved than the more serious problem of meeting specifications with repeatable uniform mechanical properties. 
FIGURE 1. Typical $\eta, \mathrm{Ni}_{3}$ Ti Precipitation in an Early JBK-75 Forging

$400 x$

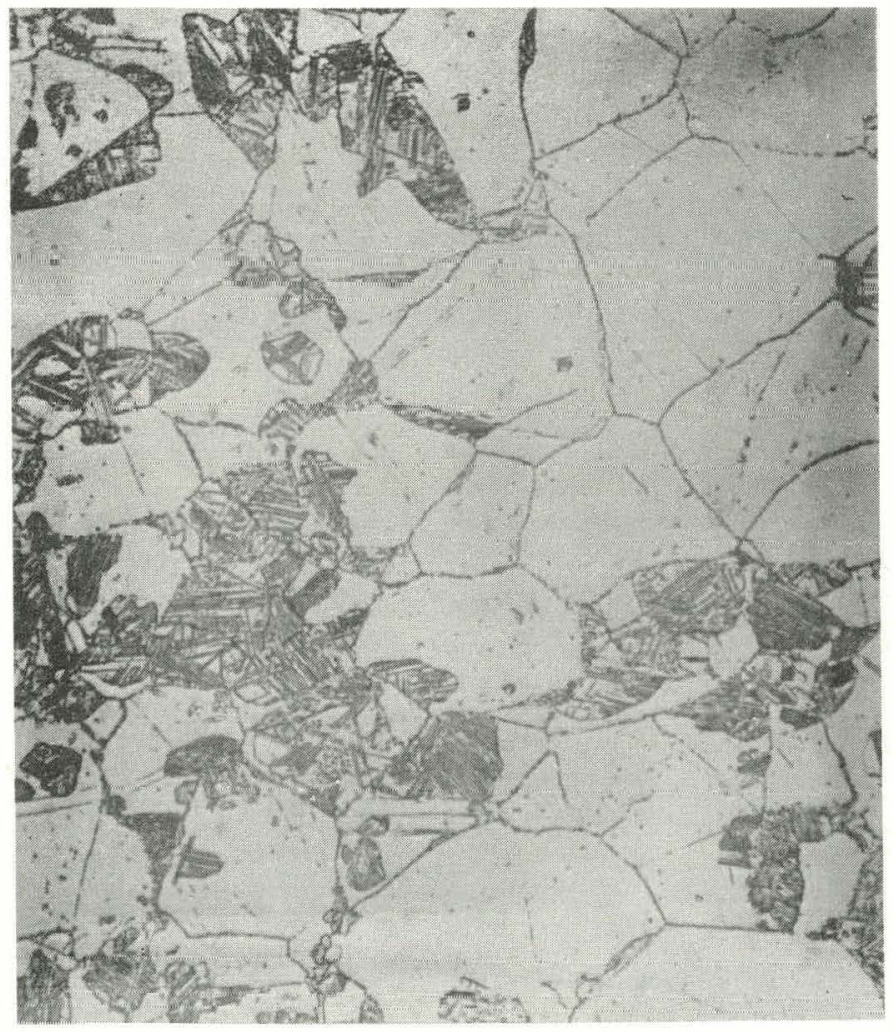

$100 x$

FIGURE 2. Typical Banding With Heavy Precipitation of $\eta, \mathrm{Ni}_{3} \mathrm{Ti}$ Phase Within Darker Regions

$500 x$
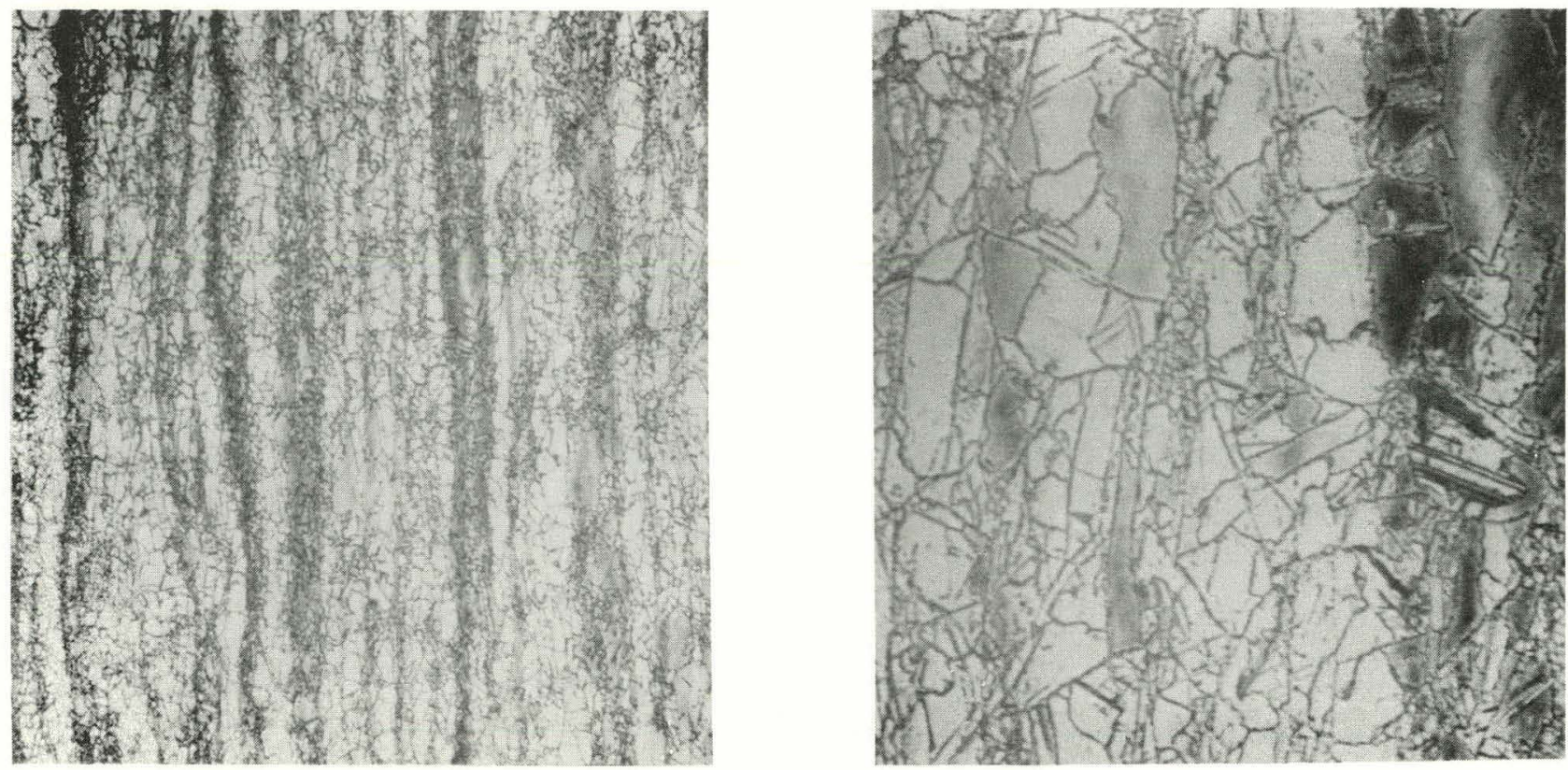
RFP-2692

FIGURE 3. JBK-75 High Energy Rate Forged (HERF'ed)

Stainless Steel Parts With Cross Reference of Identifications

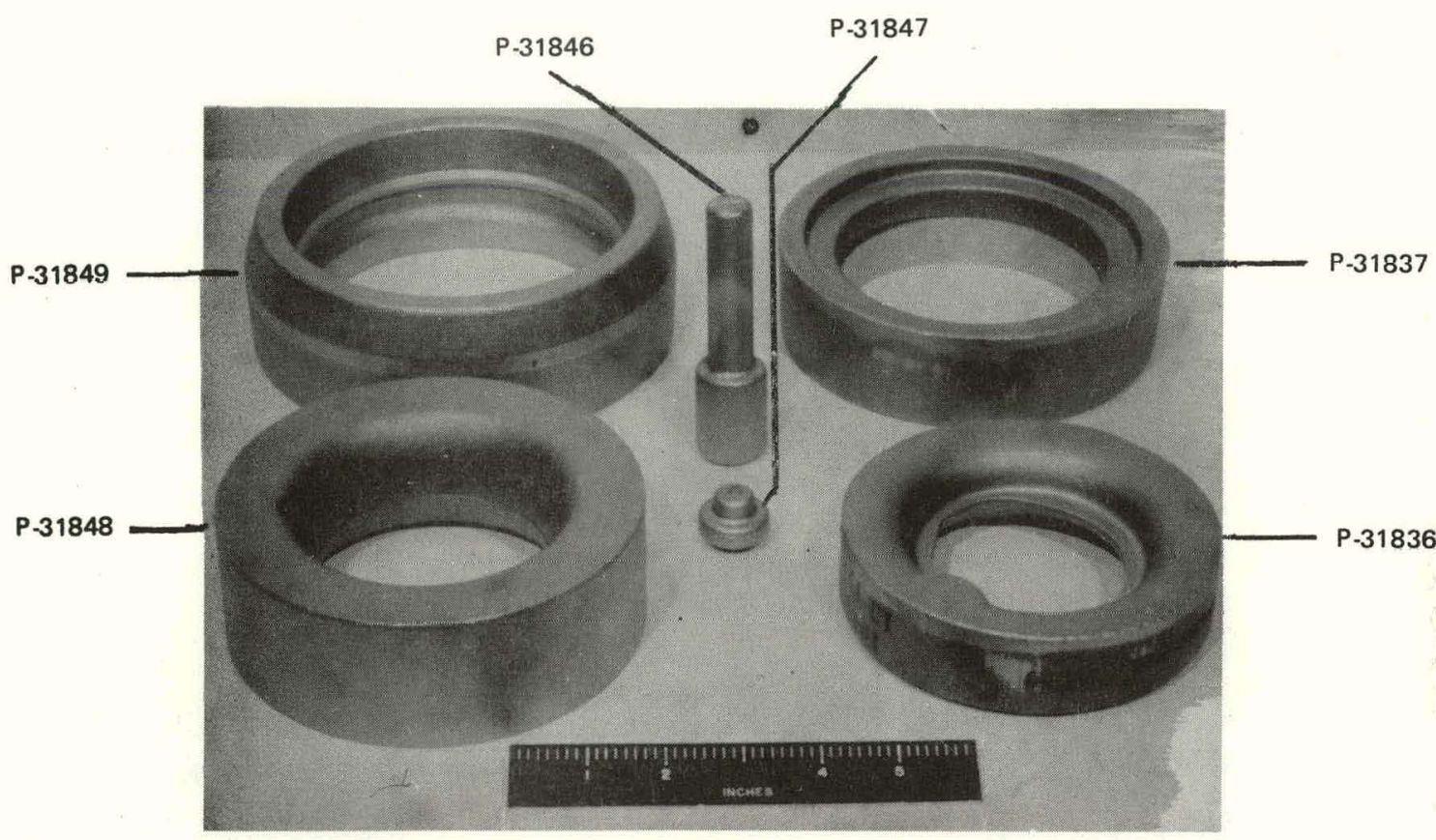

$$
\begin{aligned}
& \text { P-31836* }=\text { Small Inner Torroid }=\text { Die 812** } \\
& \text { P-31837 = Small Outer Torroid }=\text { Die } 811 \\
& \mathrm{P}-31846=\text { Stem }=\text { Die } 807 \\
& \mathrm{P}-31847=\mathrm{Cap} / \text { Button }=\text { Die } 808 / 865 \\
& \text { P-31848 = Large Inner Torroid }=\text { Die } 810 \\
& \text { P-31849 = Large Outer Torroid }=\text { Die } 809
\end{aligned}
$$

*Specification drawing number

**Current tooling number used for respective forging 
FIGURE 4. Typical Sectioning Schematic for Torroidal Forgings With Specimen Orientation Defined

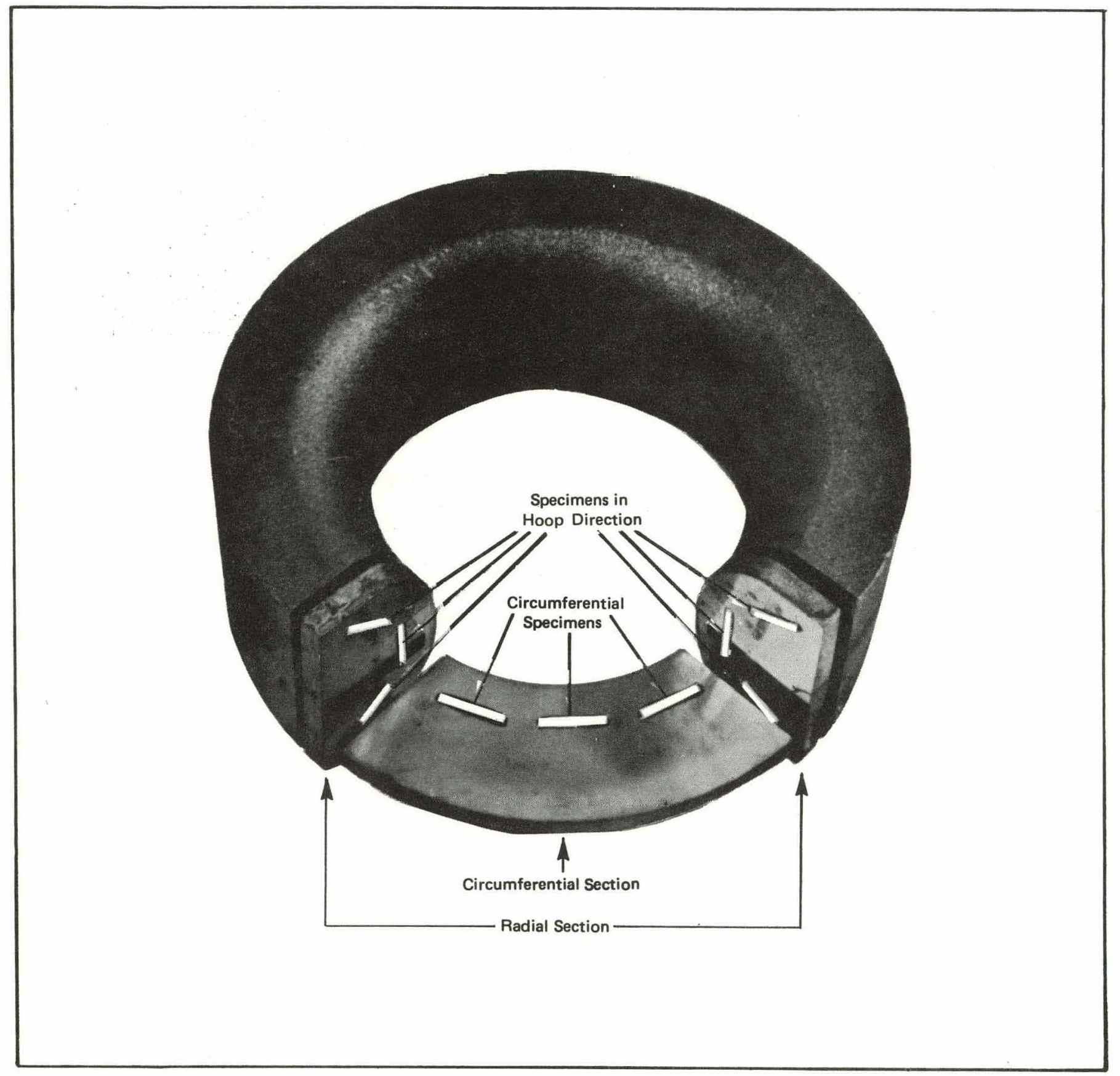




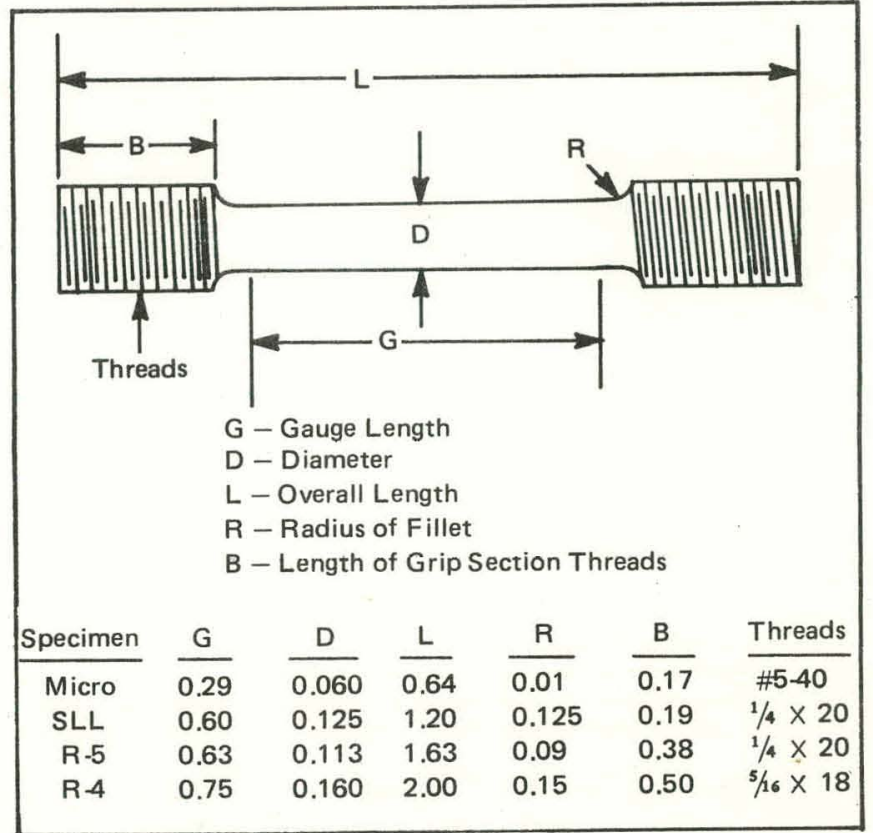

FIGURE 5. Dimensions, in Inches, of Tensile Specimens Used in This Study

FIGURE 6. Defined Tensile Properties Obtained From Load-Deflection Tensile-Test Curves

$$
\begin{array}{ll}
\frac{\text { Legend }}{\text { Ultimate Tensile Strength (UTS) }} & =\frac{\mathrm{A}}{\text { Area }} \\
\text { Tensile Yield Strength (YS) } & =\frac{\mathrm{B}}{\text { Area }} \\
\text { Total Plastic Elongation }\left(\mathrm{E}_{\mathrm{t}}\right) & =\mathrm{G}-\mathrm{F} \\
\text { Uniform Plastic Elongation }\left(\mathrm{E}_{\mathrm{u}}\right) & =\mathrm{D}-\mathrm{C} \\
\text { Total Elongation (Sandia) } & =\mathrm{H}-\mathrm{J} \\
\text { Uniform Elongation (Sandia) } & =\mathrm{I}-\mathrm{J}
\end{array}
$$

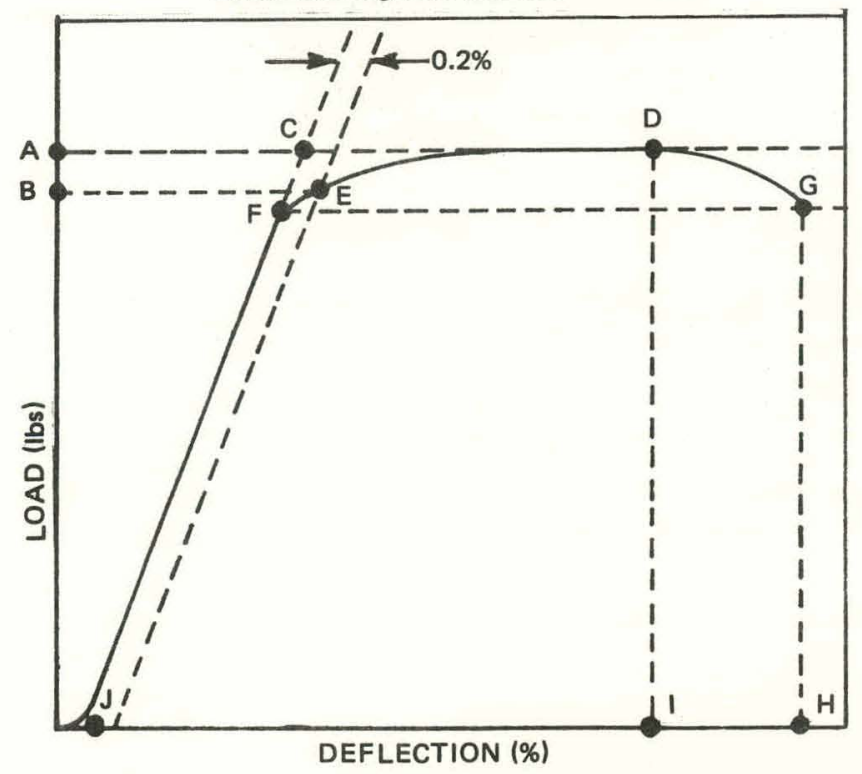


FIGURE 7. Typical Strain Rate Sensitivity Defects Found in HERF-

JBK-75 Forgings at low Forging Furnace Temperatures $\left(\sim 1650^{\circ} \mathrm{F}\right)$

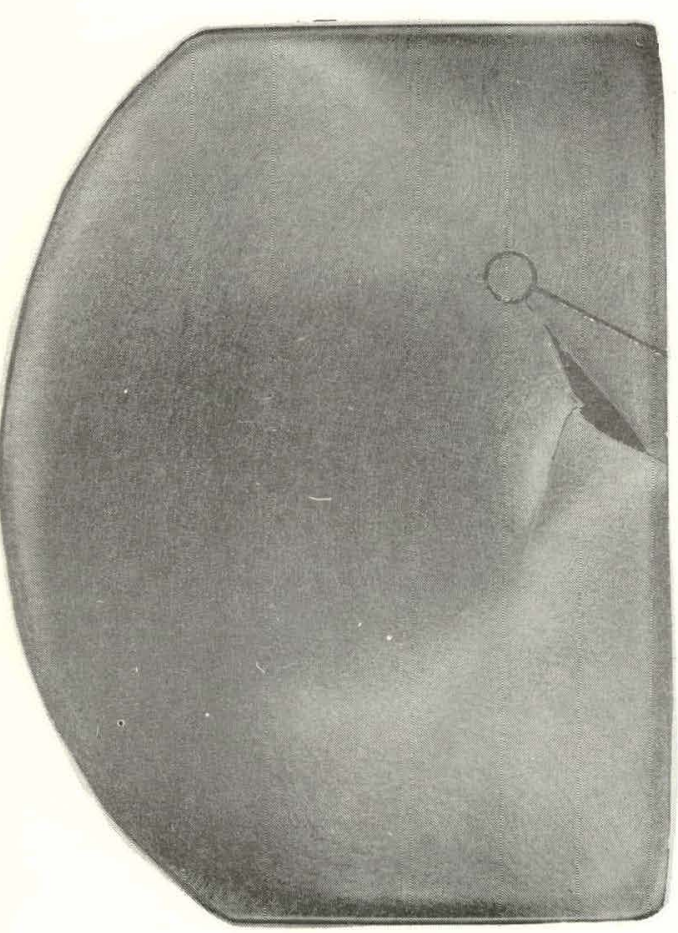

$2 x$

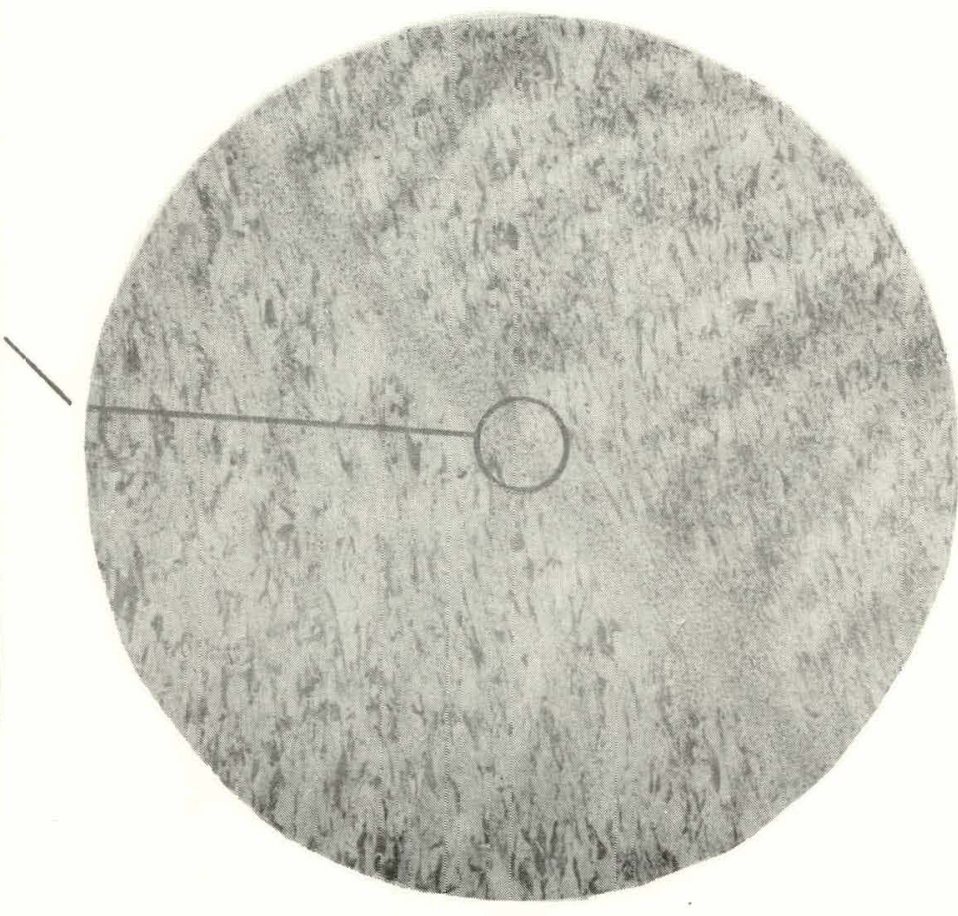

$50 x$

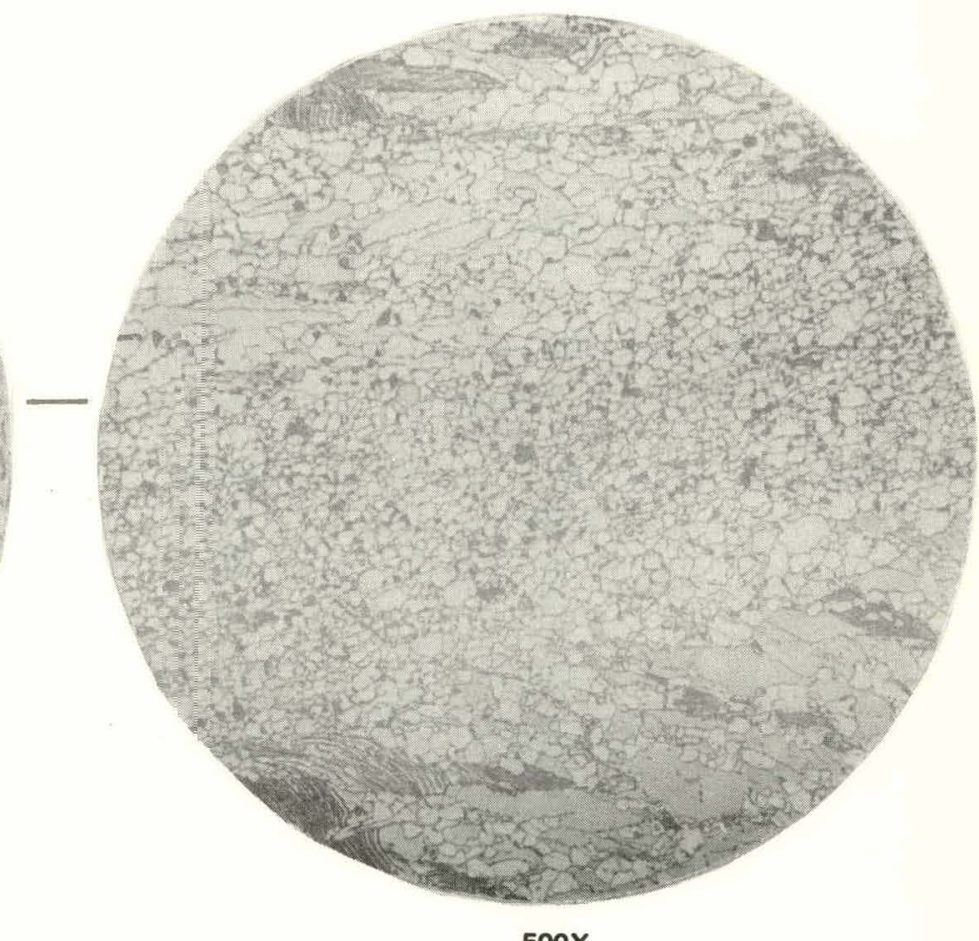

$500 x$

ADIABATIC SHEAR PLANES: Planar metal flow characterized by a narrow zone of spontaneously recrystallized grains usually terminating in a crack. 
FIGURE 7. (Continued).
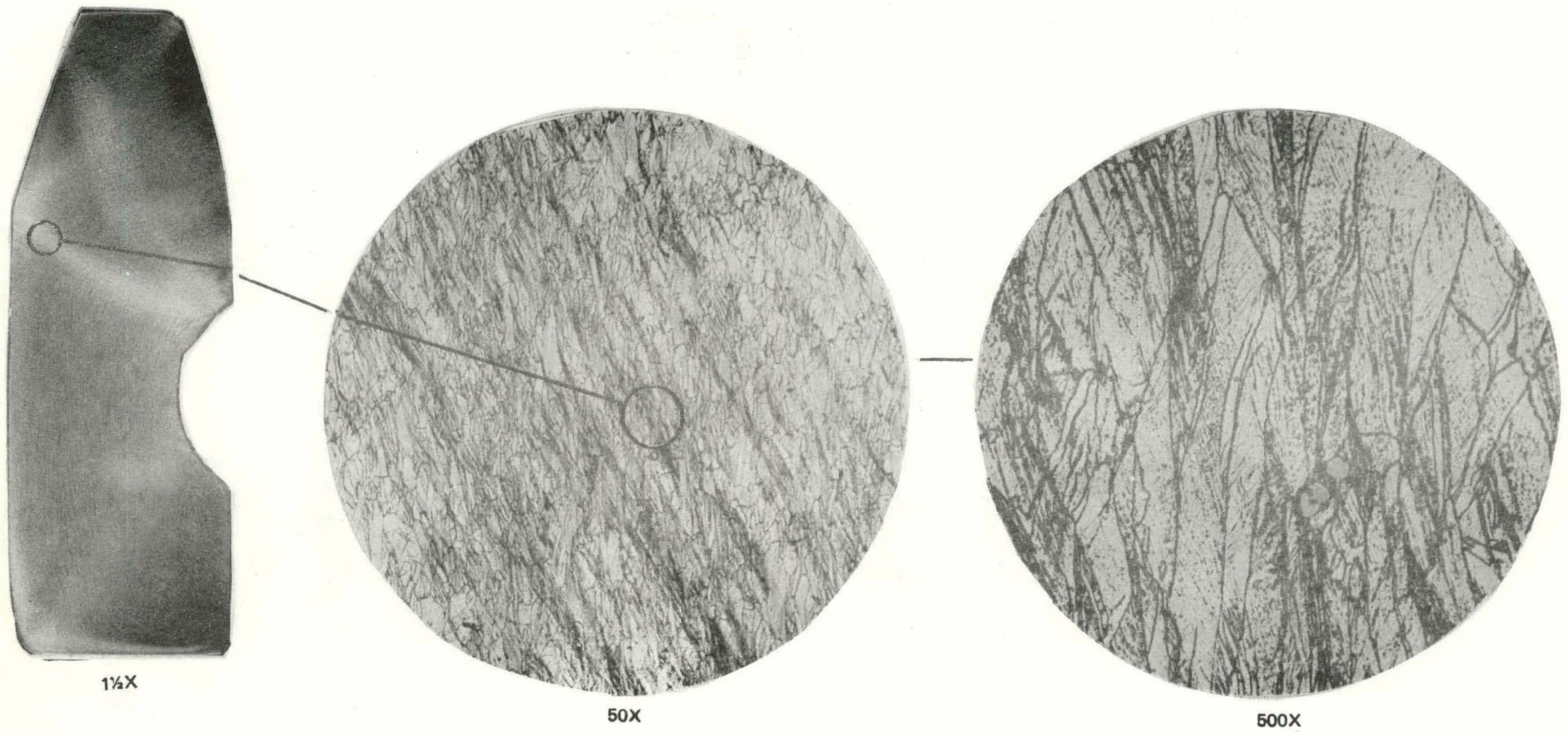

"FEATHERING": Broad planar metal flow characterized by bands of strain induced $\eta$ phase precipitation. 
FIGURE 8. Mechanical Properties and Grain Flow of Stem Forging Die 807<smiles>C1=CC=CC=CC=CC=CC=C1</smiles>

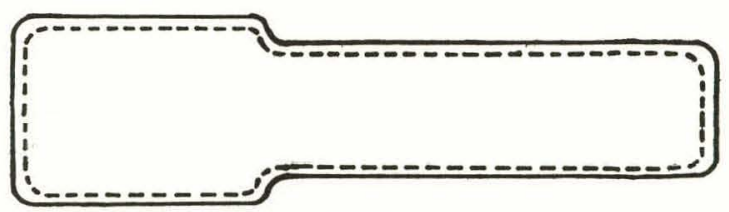

Minimum and Maximum Forging Dimensions
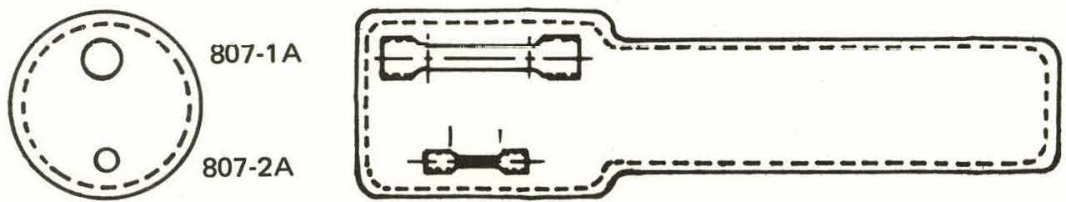

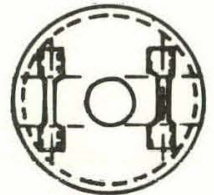

$807-4 \mathrm{H}$

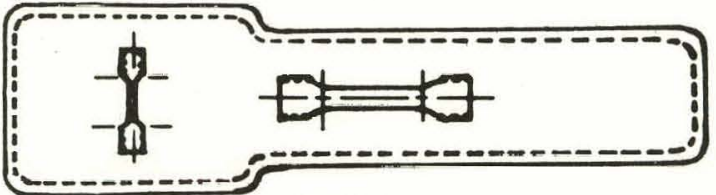

807-5A

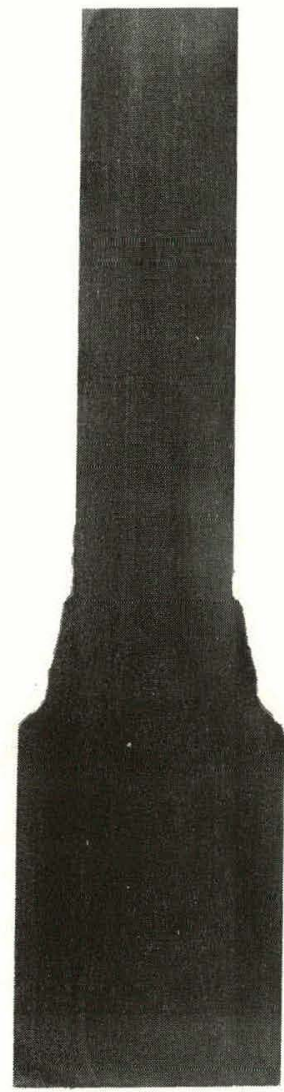

\begin{tabular}{|c|c|c|c|c|c|c|c|}
\hline \multirow[b]{2}{*}{$\begin{array}{c}\text { Bar } \\
\text { Stock }\end{array}$} & \multirow[b]{2}{*}{ Forging Parameters } & \multicolumn{6}{|c|}{ Mechanical Properties } \\
\hline & & $\begin{array}{c}\text { Sample } \\
\text { I.D. }\end{array}$ & $\begin{array}{l}\text { YS } \\
\text { (ksi) }\end{array}$ & $\begin{array}{l}\text { UTS } \\
\text { (ksi) }\end{array}$ & $\begin{array}{l}E_{u} \\
(\%)\end{array}$ & $\begin{array}{l}E_{t} \\
(\%)\end{array}$ & $\begin{array}{l}\text { RA } \\
(\%)\end{array}$ \\
\hline & & $1 \mathrm{~A}$ & 152.0 & 183.7 & 10.9 & 19.2 & 46.1 \\
\hline & & $2 A$ & 150.3 & 179.8 & 12.2 & 19.4 & 53.5 \\
\hline Teledyne & I: $1975^{\circ} \mathrm{F}-\mathrm{W} . \mathrm{Q}$. & $3 \mathrm{H}$ & 147.3 & 176.0 & 11.4 & 17.3 & 42.4 \\
\hline H-2448 & II: $1725^{\circ} \mathrm{F}-\mathrm{W} . \mathrm{Q}$. & $4 \mathrm{H}$ & 148.1 & 176.4 & 11.6 & 17.6 & 39.3 \\
\hline & & $5 \mathrm{~A}$ & 100.4 & 161.6 & 26.2 & 31.7 & 40.9 \\
\hline
\end{tabular}


FIGURE 9. Mechanical Properties of Cap Forging Die 865

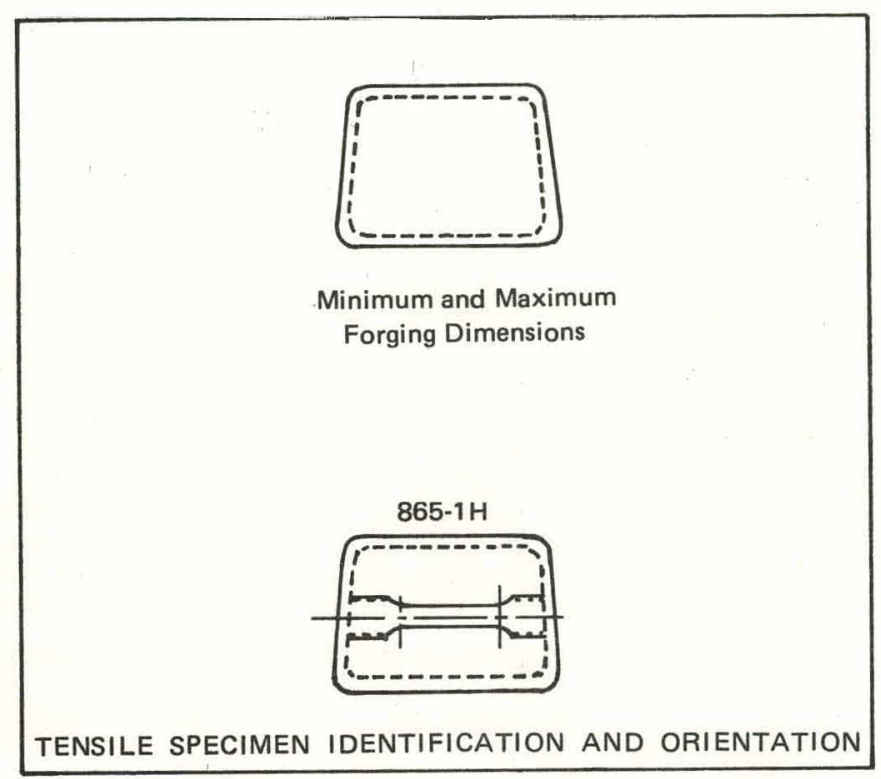

\begin{tabular}{|c|c|c|c|c|c|c|c|}
\hline \multirow[b]{2}{*}{$\begin{array}{c}\text { Bar } \\
\text { Stock }\end{array}$} & \multirow[b]{2}{*}{ Forging Parameters } & \multicolumn{6}{|c|}{ Mechanical Properties } \\
\hline & & $\begin{array}{c}\text { Sample } \\
\text { I.D. }\end{array}$ & $\begin{array}{c}\begin{array}{c}\text { YS } \\
(\mathrm{ksi})\end{array} \\
\end{array}$ & $\begin{array}{l}\text { UTS } \\
\text { (ksi) }\end{array}$ & $\begin{array}{r}\mathrm{E}_{\mathrm{u}} \\
(\%) \\
\end{array}$ & $\begin{array}{l}\mathrm{E}_{\mathrm{t}} \\
(\%)\end{array}$ & $\begin{array}{l}\text { RA } \\
(\%)\end{array}$ \\
\hline $\begin{array}{l}\text { Teledyne } \\
\text { H-2448 }\end{array}$ & $\begin{array}{l}\text { I: } 1900^{\circ} \mathrm{F}-\text { W.Q. } \\
\text { II: } 1725^{\circ} \mathrm{F} \text { - W.Q. }\end{array}$ & $1 \mathrm{H}^{*}$ & 146.5 & 180.1 & 13.4 & 19.2 & 43.0 \\
\hline
\end{tabular}

*Microbar used instead of SLL $1 / 8$ in. dia. gage as shown due to undersized forgings. 
FIGURE 10. Mechanical Properties and Grain Flow of Large Outer Torroid Forging Die 809
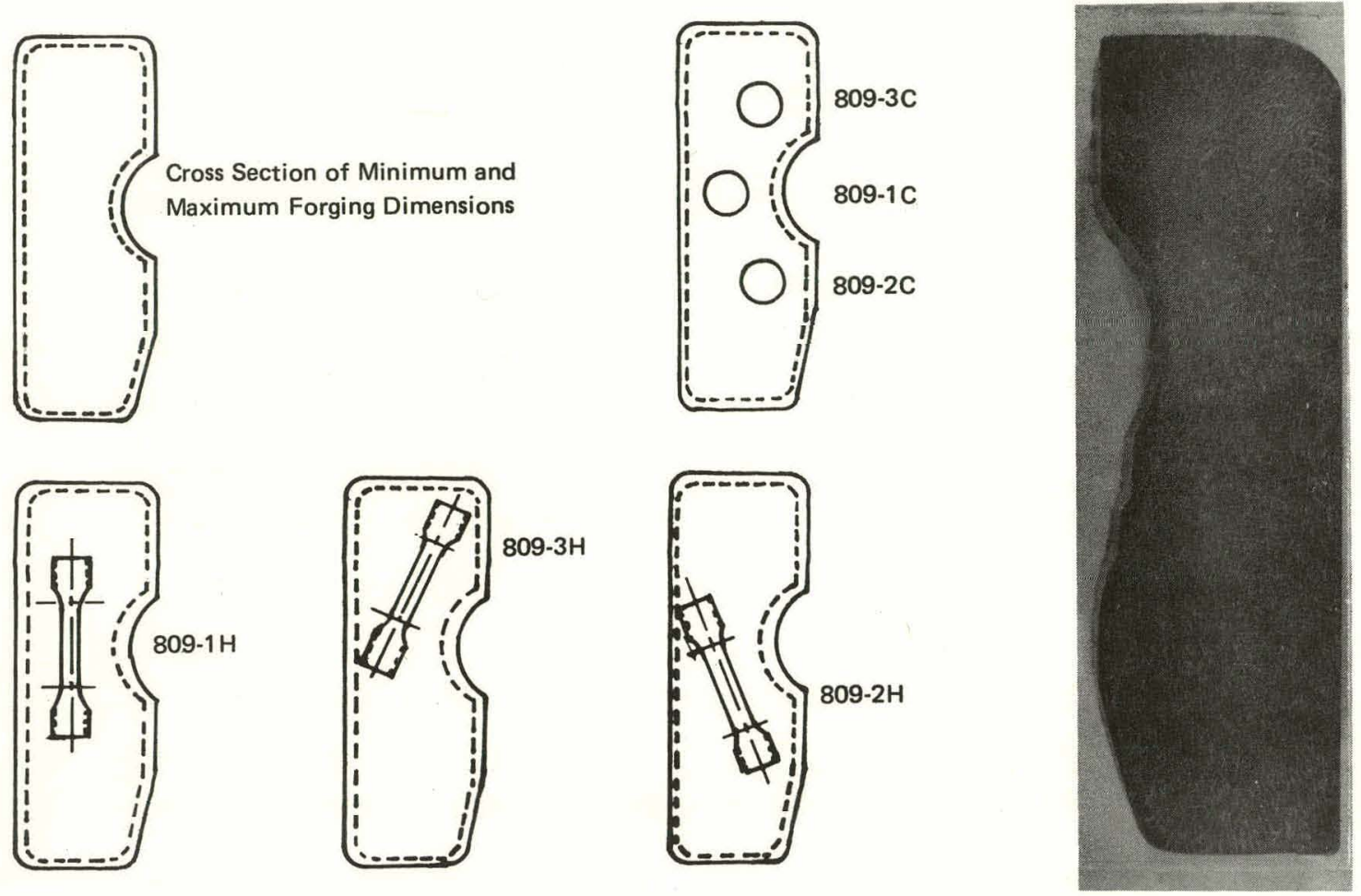

Mechanical Properties

\begin{tabular}{|c|c|c|c|c|c|c|c|}
\hline $\begin{array}{c}\text { Bar } \\
\text { Stock }\end{array}$ & Forging Parameters & $\begin{array}{l}\text { Sample } \\
\text { I.D. }\end{array}$ & $\begin{array}{l}\text { YS } \\
\text { (ksi) }\end{array}$ & $\begin{array}{l}\text { UTS } \\
\text { (ksi) }\end{array}$ & $\begin{array}{l}E_{u} \\
(\%)\end{array}$ & $\begin{array}{r}\mathrm{E}_{\mathrm{t}} \\
(\%)\end{array}$ & $\begin{array}{l}\text { RA } \\
(\%)\end{array}$ \\
\hline Teledyne & I: $1850^{\circ} \mathrm{F}-\mathrm{A} . \mathrm{C}$. & $2 \mathrm{H}$ & 152.5 & 181.1 & 6.5 & 11.9 & 41.3 \\
\hline $\mathrm{H}-927$ & II: $1650^{\circ} \mathrm{F}-\mathrm{W} . \mathrm{Q}$. & $3 \mathrm{H}$ & 126.5 & 166.1 & 9.6 & 13.9 & 19.5 \\
\hline Teledyne & I: $1775^{\circ} \mathrm{F}-\mathrm{W} . \mathrm{Q}$. & $2 \mathrm{H}$ & 147.3 & 170.1 & 5.5 & 12.3 & 52.2 \\
\hline H-926 & II: $1725^{\circ} \mathrm{F}$ - W.Q. & $3 \mathrm{H}$ & 141.4 & 166.2 & 8.0 & 15.2 & 42.4 \\
\hline Cartech & I: $1775^{\circ} \mathrm{F}-\mathrm{W} . \mathrm{Q}$. & $2 \mathrm{H}$ & 157.4 & 176.6 & 5.8 & 10.7 & 33.0 \\
\hline \multirow[t]{3}{*}{93491} & II: $1725^{\circ} \mathrm{F}$ - W.Q. & $3 \mathrm{H}$ & 164.0 & 169.0 & 7.0 & 10.6 & 21.5 \\
\hline & & $1 \mathrm{C}$ & 134.4 & 162.3 & 16.8 & 20.5 & 32.9 \\
\hline & & $2 \mathrm{C}$ & 138.0 & 164.7 & 12.7 & 19.0 & 30.2 \\
\hline Cartech & I: $1775^{\circ} \mathrm{F}$ - W.Q. & $3 C$ & 142.7 & 169.0 & 11.8 & 17.0 & 30.7 \\
\hline \multirow[t]{3}{*}{93491} & II: $1725^{\circ} \mathrm{F}-$ W.Q. & $1 \mathrm{H}$ & 129.3 & 154.9 & 14.8 & 22.0 & 51.5 \\
\hline & & $2 \mathrm{H}$ & 140.2 & 166.9 & 9.6 & 16.0 & 46.0 \\
\hline & & $3 \mathrm{H}$ & 127.1 & 153.9 & 15.0 & 20.0 & 43.8 \\
\hline
\end{tabular}


FIGURE 11. Mechanical Properties and Grain Flow of Large Inner Torroid Forging Die 810

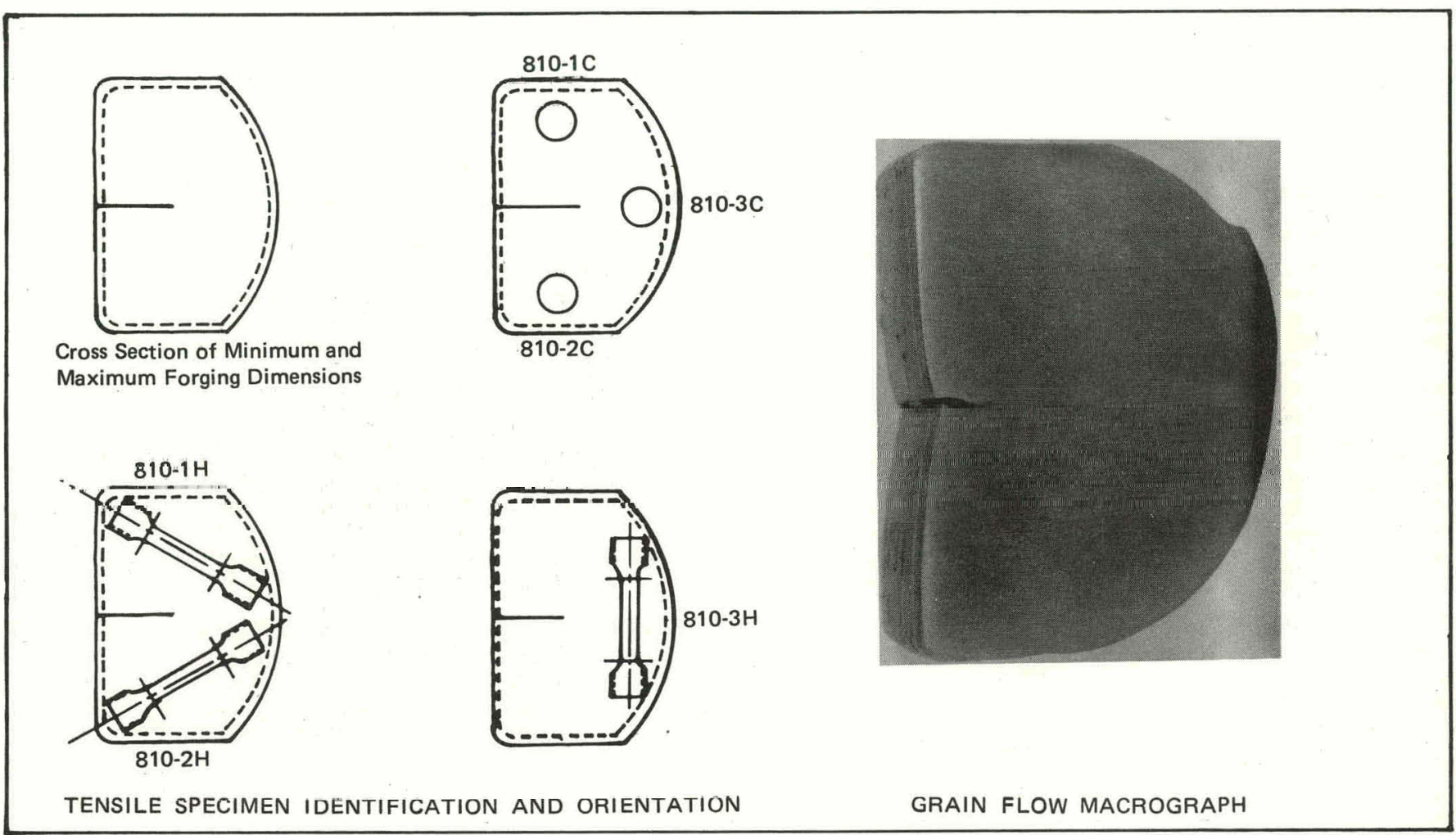

\begin{tabular}{|c|c|c|c|c|c|c|c|}
\hline $\begin{array}{l}\text { Bar } \\
\text { Stock }\end{array}$ & Forging Parameters & $\begin{array}{c}\text { Sample } \\
\text { I.D. }\end{array}$ & $\begin{array}{l}\text { YS } \\
\text { (ksi) }\end{array}$ & $\begin{array}{l}\text { UTS } \\
\text { (ksi) }\end{array}$ & $\underset{(\%)}{\mathrm{E}_{\mathrm{u}}}$ & $\begin{array}{l}\mathrm{E}_{\mathrm{t}} \\
(\%)\end{array}$ & $\begin{array}{l}\text { RA } \\
\text { (\%) }\end{array}$ \\
\hline \multirow{3}{*}{$\begin{array}{l}\text { Teledyne } \\
\text { H-927 }\end{array}$} & I: $1850^{\circ} \mathrm{F}-\mathrm{A} . \mathrm{C}$. & $1 \mathrm{H}$ & 142.2 & 178.6 & 8.9 & 14.5 & 26.7 \\
\hline & II: $1700^{\circ} \mathrm{F}-\mathrm{A} . \mathrm{C}$. & $2 \mathrm{H}$ & 122.6 & 170.2 & 15.8 & 21.6 & 39.4 \\
\hline & III: $1650^{\circ} \mathrm{F}-$ W.Q. & $3 \mathrm{H}$ & 111.4 & 154.8 & 18.3 & 25.5 & 34.8 \\
\hline \multirow{6}{*}{$\begin{array}{c}\text { Cartech } \\
93491\end{array}$} & \multirow{6}{*}{$\begin{array}{c}\text { I: } 1800^{\circ} \mathrm{F}-\text { W.Q. } \\
\text { II: } 1775^{\circ} \mathrm{F}-\text { W.Q. } \\
\text { III: } 1725^{\circ} \mathrm{F} / 30 \text { sec. } \\
\text { A.C. - W.Q. }\end{array}$} & $1 \mathrm{C}$ & 131.0 & 166.5 & 10.9 & 23.0 & 46.3 \\
\hline & & $2 \mathrm{C}$ & 140.5 & 173.6 & 12.0 & 17.0 & 29.8 \\
\hline & & $3 \mathrm{C}$ & 126.1 & 156.7 & 22.9 & N/A & 49.6 \\
\hline & & $1 \mathrm{H}$ & 125.6 & 155.8 & 16.7 & 23.0 & 52.9 \\
\hline & & $2 \mathrm{H}$ & 128.5 & 157.4 & 11.1 & N/A & 47.1 \\
\hline & & $3 \mathrm{H}$ & 119.7 & 152.1 & 22.7 & 31.0 & 48.7 \\
\hline \multirow{6}{*}{$\begin{array}{l}\text { Teledyne } \\
\text { H-927 }\end{array}$} & \multirow{6}{*}{$\begin{array}{c}\text { I: } 1800^{\circ} \mathrm{F}-\text { W.Q. } \\
\text { II: } 1775^{\circ} \mathrm{F}-\text { W.Q. } \\
\text { III: } 1725^{\circ} \mathrm{F} / 30 \mathrm{sec} . \\
\text { A.C. - W.Q. }\end{array}$} & $1 \mathrm{C}$ & 138.0 & 171.5 & 13.3 & 19.0 & 28.1 \\
\hline & & $2 \mathrm{C}$ & 140.0 & 173.1 & 10.9 & 16.0 & 43.8 \\
\hline & & $3 \mathrm{C}$ & 126.9 & 160.3 & 21.7 & N/A & 43.0 \\
\hline & & $1 \mathrm{H}$ & 128.1 & 155.8 & 11.2 & $\mathrm{~N} / \mathrm{A}$ & 55.4 \\
\hline & & $2 \mathrm{H}$ & 133.5 & 160.7 & 11.8 & N/A & 48.8 \\
\hline & & $3 \mathrm{H}$ & 117.8 & 147.9 & 22.4 & 31.0 & 43.0 \\
\hline
\end{tabular}


RFP-2692

FIGURE 12. Mechanical Properties and Grain Flow of Small Outer Torroid Forging Die 811

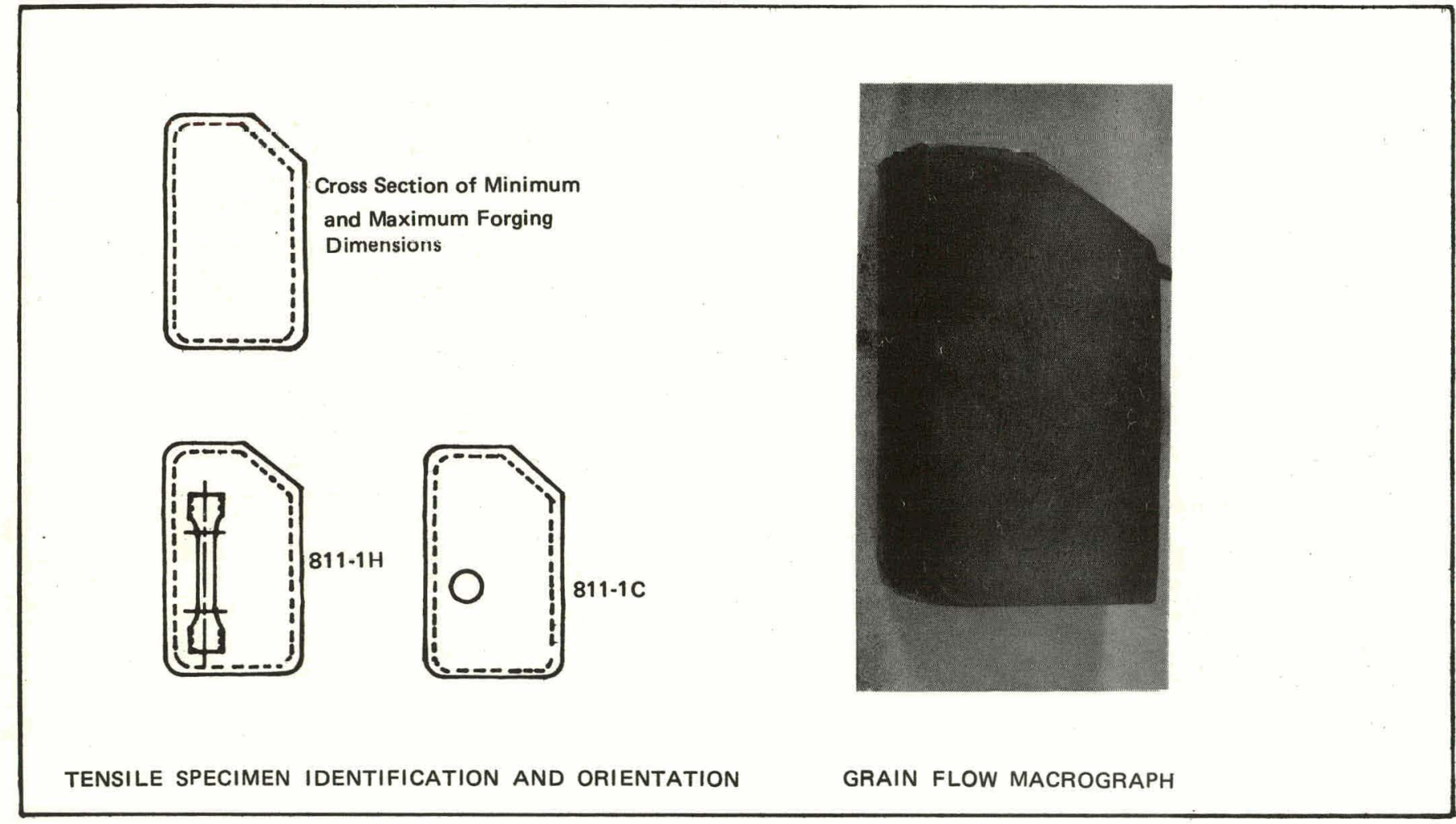

Mechanical Properties

\begin{tabular}{|c|c|c|c|c|c|c|c|}
\hline $\begin{array}{c}\text { Bar } \\
\text { Stock }\end{array}$ & Forging Parameters & $\begin{array}{c}\text { Sample } \\
\text { I.D. }\end{array}$ & $\begin{array}{l}\text { YS } \\
\text { (ksi) }\end{array}$ & $\begin{array}{l}\text { UTS } \\
\text { (ksi) }\end{array}$ & $\begin{array}{l}E_{u} \\
(\%)\end{array}$ & $\begin{array}{c}\mathrm{E}_{\mathrm{t}} \\
(\%)\end{array}$ & $\begin{array}{l}\text { RA } \\
(\%)\end{array}$ \\
\hline Cartech & I: $1775^{\circ} \mathrm{F}$ - W.Q. & $1 \mathrm{H}$ & 127.1 & 158.8 & 15.9 & 25.0 & 51.7 \\
\hline 93491 & II: $1725^{\circ} \mathrm{F}-$ W.Q. & $1 \mathrm{C}$ & 126.4 & 159.0 & 17.6 & 22.8 & 34.0 \\
\hline
\end{tabular}


FIGURE 13. Mechanical Properties and Grain Flow of Small Inner Torroid Forging Die 812

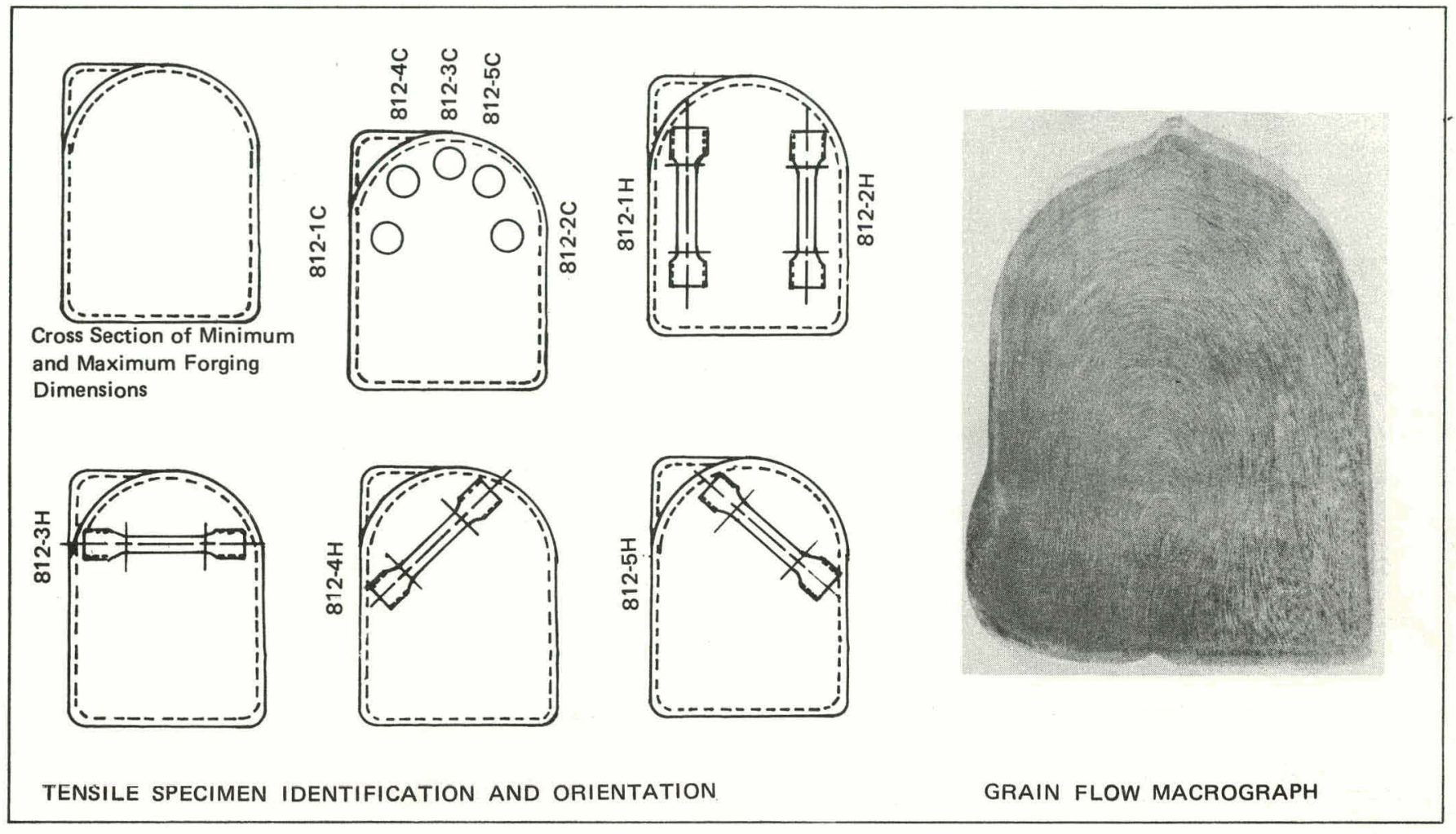

\begin{tabular}{|c|c|c|c|c|c|c|c|}
\hline \multirow[b]{2}{*}{$\begin{array}{c}\text { Bar } \\
\text { Stock }\end{array}$} & \multirow[b]{2}{*}{ Forging Parameters } & \multicolumn{6}{|c|}{ Mechanical Properties } \\
\hline & & $\begin{array}{c}\text { Sample } \\
\text { I.D. }\end{array}$ & $\begin{array}{l}\text { YS } \\
\text { (ksi) }\end{array}$ & $\begin{array}{l}\text { UTS } \\
\text { (ksi) }\end{array}$ & $\begin{array}{l}E_{u} \\
(\%)\end{array}$ & $\begin{array}{l}\mathrm{E}_{\mathrm{t}} \\
(\%)\end{array}$ & $\begin{array}{l}\text { RA } \\
(\%)\end{array}$ \\
\hline \multirow{2}{*}{$\begin{array}{l}\text { Teledyne } \\
\text { H-927 }\end{array}$} & I: $1850^{\circ} \mathrm{F}-$ A.C. & $4 \mathrm{H}$ & 137.1 & 173.2 & 10.2 & 17.0 & 44.4 \\
\hline & II: $1650^{\circ} \mathrm{F}-\mathrm{W} . \mathrm{Q}$. & $5 \mathrm{H}$ & 130.4 & 164.7 & 7.6 & 14.3 & 47.7 \\
\hline \multirow{2}{*}{$\begin{array}{l}\text { Teledyne } \\
\text { H-2448 }\end{array}$} & I: $1775^{\circ} \mathrm{F}-$ W.Q. & $4 \mathrm{H}$ & 135.2 & 167.4 & 12.2 & 23.2 & 60.2 \\
\hline & II: $1725^{\circ} \mathrm{F}-\mathrm{W} . \mathrm{Q}$. & $5 \mathrm{H}$ & 127.7 & 159.8 & 13.8 & 24.9 & 57.8 \\
\hline \multirow{3}{*}{$\begin{array}{c}\text { Cartech } \\
93491\end{array}$} & \multirow{3}{*}{$\begin{array}{l}\text { I: } 1775^{\circ} \mathrm{F} \text { - W.Q. } \\
\text { II: } 1725^{\circ} \mathrm{F} \text { - W.Q. }\end{array}$} & $3 \mathrm{H}$ & 117.5 & 143.5 & 14.8 & 22.3 & 49.2 \\
\hline & & $4 \mathrm{H}$ & 120.8 & 150.1 & 14.9 & 23.8 & 57.8 \\
\hline & & $5 \mathrm{H}$ & 122.5 & 148.6 & 14.8 & 23.9 & 49.1 \\
\hline \multirow{10}{*}{$\begin{array}{c}\text { Cartech } \\
93491\end{array}$} & \multirow{10}{*}{$\begin{array}{c}\text { I: } 1775^{\circ} \mathrm{F}-\text { W.Q. } \\
\text { II: } 1725^{\circ} \mathrm{F} / 30 \text { sec. } \\
\text { A.C. - W.Q. }\end{array}$} & $1 \mathrm{C}$ & 140.7 & 173.4 & 12.0 & 17.5 & 36.8 \\
\hline & & $2 \mathrm{C}$ & 134.3 & 167.4 & 13.3 & 21.0 & 37.6 \\
\hline & & $3 \mathrm{C}$ & 120.3 & 154.2 & 16.2 & 26.5 & 44.3 \\
\hline & & $4 \mathrm{C}$ & 122.1 & 154.4 & 14.6 & 23.5 & 37.6 \\
\hline & & $5 \mathrm{C}$ & 120.9 & 154.4 & 20.0 & 27.0 & 39.7 \\
\hline & & $1 \mathrm{H}$ & 139.7 & 168.0 & 8.7 & 16.0 & 36.6 \\
\hline & & $2 \mathrm{H}$ & 135.6 & 165.7 & 12.6 & 16.0 & 40.1 \\
\hline & & $3 \mathrm{H}$ & 125.0 & 154.4 & 13.1 & 20.5 & 37.9 \\
\hline & & $4 \mathrm{H}$ & 127.5 & 158.9 & 10.5 & 14.5 & 24.8 \\
\hline & & $5 \mathrm{H}$ & 126.1 & 158.8 & 13.5 & 19.0 & 38.4 \\
\hline
\end{tabular}


RFP-2692 